\title{
ESCRAVISMO COLONIAL, ARQUEOLOGIA E LIVROS DIDÁTICOS
}

Semana Online Científica de Educação, 1a edição, de 25/10/2021 a 27/10/2021

ISBN dos Anais: 978-65-81152-18-5

SILVA; Leandro Vieira da ${ }^{1}$

\section{RESUMO}

Esse trabalho procurou analisar e sistematizar passagens textuais e referências ilustrativas sobre a história dos grupos escravizados no Brasil que estão retratadas em livros didáticos nos níveis fundamental e médio, publicados a partir de 2003 e usados na rede pública. A justificativa pela escolha desse ano se deve à promulgação da Lei 10.639/2003, em que se tornou obrigatória a presença de um capítulo sobre a História da África nos livros de história. Nesse sentido, o objetivo dessa pesquisa foi verificar se diante da obrigatoriedade de conteúdos relativos ao continente africano, se houve alguma mudança sobre as informações relativas aos grupos escravizados no Brasil. Nos livros consultados, foram observadas certas representações que ainda demonstram anacronismos e estereótipos, isso quando uma determinada temática é completamente ignorada. Nesse sentido, dois exemplos podem ser citados, uma é a falta de referência sobre os quilombos, locais que os escravos se refugiavam e que, atualmente, são importantes sítios arqueológicos. E o outro exemplo, é a persistência da invisibilidade do escravismo nas atividades ligadas à pecuária extensiva, quando se já descobriu várias senzalas nesse contexto. Esse silêncio apenas reforça a idéia errônea de que o escravismo esteve presente somente em plantations, na mineração e nas cidades. Diante desse resultado, é preciso refletir sobre como o estudo sobre o passado dos escravos afrobrasileiros está sendo representado e como isso repercute no tempo presente. As poucas alusões que aparecem nas obras não estão acompanhando os recentes achados arqueológicos e permanecem eivadas de concepções que vieram de interpretações formuladas ao longo do século XX. Se a Arqueologia tem o potencial de desmitificar certos aspectos que estão impregnados pelo senso comum ou mesmo de rebater determinados entendimentos ultrapassados, resta aos autores dessas obras ampararem seus textos nas pesquisas que estão em andamento, reavaliando posições e acrescentando novos dados.

PALAVRAS-ChAVE: Livro Didático, Ensino de História, Escravismo, Arqueologia, História do Brasil 